\title{
Current status of intestinal parasitic infections among inhabitants of the Ghazni and Parwan provinces, Afghanistan
}

\author{
KRZYSZTOF KORZENIEWSKI ${ }^{1, A-F}$, WON CHIN CHUNG ${ }^{2, \text { B }}$, ALINA AUGUSTYNOWICZ ${ }^{1, B}$, \\ ANNA LASS ${ }^{3, \text { B }}$, KIM JONG IK², F \\ ${ }^{1}$ Department of Epidemiology and Tropical Medicine in Gdynia, Military Institute of Medicine in Warsaw, Poland \\ ${ }^{2}$ Korean Hospital, Bagram Airfield U.S. military base, Afghanistan \\ ${ }^{3}$ Department of Tropical Parasitology in Gdynia, Medical University of Gdansk, Poland
}

A - Study Design, B - Data Collection, C - Statistical Analysis, D - Data Interpretation, E - Manuscript Preparation, F - Literature Search, G - Funds Collection

\begin{abstract}
Summary Background. The prevalence rates of food- and waterborne parasitic infections in Afghanistan are unknown. Cases of invasive diseases found in Afghans are rarely laboratory-confirmed.

Objectives. The aim of the study was to present the current status of intestinal parasitic infections in Afghan inhabitants on the example of patients hospitalized in two healthcare facilities in eastern Afghanistan.

Material and methods. Fecal samples were collected from 548 patients (children aged 1-17 years and adults) with internal complaints, treated in Ghazni Provincial Hospital (Afghan civilian medical center, Ghazni province, 180 south-west of Kabul) and in Bagram Korean Hospital (Korean military medical center for Afghan patients, Parwan province, $60 \mathrm{~km}$ north of Kabul) between 2013 and 2014 . One to three stool specimens from Afghan patients were fixed in $10 \%$ formalin, transported to the Military Institute of Medicine in Poland and tested by light microscopy using three diagnostic methods (direct smear in Lugol's solution, decantation in distilled water and Fülleborn's flotation).

Results. Intestinal parasites were found in 144/386 of tested patients from the Ghazni province (37.3\% infected, mainly with Ascaris lumbricoides, Giardia intestinalis, Hymenolepis nana) and in 49/162 patients from the Parwan province (30.2\% infected, mainly with G. intestinalis, A. lumbricoides, H. nana).

Conclusions. The rates of intestinal parasitic infections among Afghans are high. The wide range of the detected parasites (protozoa, nematodes, cestodes) should result in the introduction of general screening to be conducted regularly among inhabitants of Afghanistan and the application of targeted antiparasitic chemotherapy aiming to eliminate intestinal helminths and protozoa from the local community.
\end{abstract}

Key words: intestinal parasites, helminths, protozoa, Afghanistan.

Korzeniewski K, Chung WC, Augustynowicz A, Lass A, lk KJ. Current status of intestinal parasitic infections among inhabitants of the Ghazni and Parwan provinces, Afghanistan. Fam Med Prim Care Rev 2017; 19(1): 23-28, doi: 10.5114/fmpcr.2017.65087.

\section{Background}

The prevalence rates of intestinal parasitic infections in Afghanistan are unknown. Cases of invasive diseases found among Afghans are rarely laboratory-confirmed. The shortage of medical staff at all levels of the healthcare system hampers the implementation of epidemiological surveillance and makes it difficult to reduce the number of the sick and carriers. The Afghan healthcare system is heavily dependent on humanitarian aid provided by international NGOs [1]. It is estimated that the risk of developing food- or waterborne diseases in Afghanistan is high [2]. No more than $55 \%$ of people living in Afghanistan have access to uncontaminated drinking water $(78 \%$ in urban and $47 \%$ in rural areas), and only $32 \%$ have access to toilet facilities which meet sanitary requirements [3]. 27\% of Afghans are estimated to be chronically undernourished; this especially applies to children [4]. Poor hygiene practices and ignorance of preventive healthcare principles do not help improve the situation. Afghanistan is one of the few members of the Organization of the Islamic Conference with no official data on the prevalence of gastrointestinal parasitic diseases in its population [5]. Reports on the prevalence of parasitic infections in Afghan refugees arriving in the USA or in Europe are also rarely issued. In the 1980s, stool samples were examined from 51 Afghans arriving in the USA. The study found that $32 \%$ of the subjects were infected with Ascaris lumbricoides, Giardia intestinalis, Entamoeba histolytica, Hymenolepis nana and Trichuris trichiura [6]. Between 1997 and 2003, 5,928 Afghan refugees arriving in Sweden were tested for giardiasis; 225 of the study subjects (3.8\%) were infected with Giardia intestinalis [7]. Another 687 Afghan refugees were tested for giardiasis and hymenolepiasis in Pakistan between 2007 and 2009. In total, 259 (37.7\%) samples were found to be positive for Giardia intestinalis and 213 (31\%) for Hymenolepis nana [8].

In 2003, workers with the World Health Organization tested stool samples from 1,001 children frequenting schools in four Afghan provinces (Kabul, Nangarhar, Farah, Kandahar). The study demonstrated that $47 \%$ of the children were infected with gastrointestinal helminthiases, the most common parasite being Ascaris lumbricoides, found in $40.9 \%$ of the examined children. WHO employees who had conducted the study suggested the introduction of a regular single-dose therapy to treat parasitic infections (albendazole $400 \mathrm{mg}$ or mebendazole 500 $\mathrm{mg}$ ) as a cost-effective method of controlling soil-transmitted helminthiases [9]. In 2004, The United Nations World Food Programme, in cooperation with WHO, UNICEF and the Afghan Ministries of Health and Education, conducted a deworming campaign among 4.5 million Afghan children aged 6-12, frequenting approximately 7,000 schools throughout Afghanistan; all the children received a single dose of mebendazole [10]. 
WHO recommends annual mass antihelminthic treatment for all school children in areas where the prevalence of intestinal parasites is $>20 \%$, or twice a year when the prevalence is $>50 \%$ [11].

Unfortunately, the deworming campaigns carried out over the last several years in the Middle East and in Central Asia have been unsuccessful. In 2011 , only $0.69 \%$ of schoolchildren in the Eastern Mediterranean Region (including Afghanistan) received antiparasitic therapy (albendazole or mebendazole) [12]. The failure was primarily due to the unstable geopolitical situation in the region, especially in the Levant and in Afghanistan.

The events of September 11, 2001 led to the formation of multinational coalition forces to fight the Taliban forces in Afghanistan. Several dozen nations have deployed their troops to Afghanistan since 2002. Foreign military and civilian personnel have been organized into Provincial Reconstruction Teams (PRTs), whose aim, among others, is to provide the local population with humanitarian assistance. Polish and Korean PRTs became actively involved in healthcare provision and agreed to cooperate on the project of parasitological testing. Their activities led to the identification of the most prevalent intestinal parasites in the Afghan population and allowed them to estimate current infection rates in the country. The study results show that it is absolutely necessary to use targeted antiparasitic chemotherapy in order to successfully eradicate intestinal pathogens from Afghanistan.

\section{Objectives}

The purpose of the study was to present the current status of intestinal parasitic infections in the Afghan community on the example of patients hospitalized in two medical centers in the eastern part of the country.

\section{Material and methods}

\section{Study population}

Fecal samples were collected from 386 patients (179 children aged 1-17 years and 207 adults) with internal complaints treated in Ghazni Provincial Hospital (Ghazni province, 180 south-west of Kabul) between March and April 2013, as well as from 162 patients (93 children aged 1-17 years and 69 adults) with internal complaints treated in Bagram Korean Hospital (Parwan province, Bagram Airfield U.S. military base, $60 \mathrm{~km}$ north of Kabul) between October and November 2014.

\section{Organization of the surveyed medical centers}

Ghazni Provincial Hospital (GPH) is the biggest Afghan medical facility in the capital of the Ghazni province, populated by the Pashtun ethnic group. It is divided into five wards: internal, tuberculosis, pediatric, obstetrics and gynecology and general surgery. The hospital has an operating block, blood bank, laboratory, X-ray facilities and an outpatient clinic. 160 Afghan medical staff members are employed in GPH, including 31 physicians. Laboratory diagnostics is below modern standards, and all testing equipment is outdated. All medications are provided by the hospital's sponsors - the International Drug Association and the Bakhtar Development Network.

The Korean Hospital was a military medical facility dedicated to the local Afghan population (Pashtun, Tajiks, less often Hazara), located at the Bagram Airfield U.S. Forces base. It was established by the Korean International Cooperation Agency and the Inje University Paik Hospital in Seoul in 2008 to provide medical assistance to Afghan patients and educate Afghan healthcare providers (medical training in Afghanistan and in Korea). The Korean Hospital, which operated until July 2015, consisted of the general surgery ward, internal ward, outpatient clinic, laboratory and X-ray facilities. The hospital employed 63 staff members, including 21 Koreans (supervisors, including 5 physicians) and 42 Afghans (subordinates, 6 physicians).

\section{Sample collection and examination}

One to three stool specimens (1.0-1.5 g collected in plastic vials at 2-day intervals) from Afghan patients treated in Ghazni Provincial Hospital and in Bagram Korean Hospital were fixed in $10 \%$ formalin, transported to the Military Institute of Medicine in Poland and tested by light microscopy using three diagnostic methods (direct smear in Lugol's solution, decantation with distilled water and Fülleborn's flotation) [14-16].

\section{Ethical considerations}

The research project entitled 'The assessment of the prevalence of intestinal parasitic infections in the Afghan population on the example of patients treated in Ghazni Provincial Hospital (Ghazni province) and the Korean Hospital in Bagram Airfield (Parwan province)' was accepted by the Committee on Bioethics in the Military Institute of Medicine (Decision No. 3/2015, 21 Jan 2015) on the basis of the Declaration of Helsinki (1996) and the rules elaborated upon by the European Union on 'Good clinical practice for trails on medical products in the European Community. The rules governing medical products in the European Community' (1990), ratified by the Polish Ethics Committee (March 1993).

\section{Statistical analysis}

Statistical analyses have been performed using the statistical suite STATISTICA version 10.0. (StatSoft. Inc. (2011) www. statsoft.com (SNJGNP3087539302AR-E)) and Excel. The quantitative variables were characterized by the arithmetic mean of standard deviation or median or max/min (range) and $95 \%$ confidence interval. The qualitative variables were presented with the use of count and percentage. The statistical significance of differences between two groups (unpaired variables model) was processed with the $t$-Student test (or Welch test in the case of lack of homogeneity) or Mann-Whitney $U$ test (in cases where conditions of performing the $t$-Student test were not satisfied or for variables measured by the ordinal scale). Chisquared tests for independence were used for qualitative variables (with the use of Yates correction for cell counts below 10, with a check of Cochrane's conditions or with Fisher's exact test, respectively). In order to determine dependence, strength and direction between variables, correlation analysis was used by determining the Pearson or Spearman's correlation coefficients. In all the calculations, the statistical significance level alpha = 0.05 has been used.

\section{Results}

Intestinal parasitic infections were found in 144/386 of patients from Ghazni Provincial Hospital (Ghazni province) tested in the period March-April 2013 and in 49/162 patients from Bagram Korean Hospital (Parwan province) tested in the period October-November 2014.

\section{Patients treated in Ghazni Provincial Hospital \\ $(n=386)$}

Intestinal parasites were found in 144 patients (37.3\%; 80 children and 64 adults). Of the 179 tested children, 85 were girls (47.5\%) and 94 were boys (52.5\%); in total, 80 children were found infected (44.7\%). Of the 207 tested adults, 116 were women (56\%) and 91 were men (44\%); in total, 64 adult patients were found to be infected (30.9\%). The mean age of children in the study population was 8.9 years (range $1-17$ years), and the differences in the prevalence rates in terms of age were not sta- 
tistically significant (the value of the Mann-Whitney $U$ test was $1.24, p=0.2149$ ). The mean age of the adult patients was 34.2 years (range 18-85 years), and no statistically significant differences in the prevalence of infections between different age groups were observed (the value of the Mann-Whitney $U$ test was $1.16, p=0.2466)$. The most common pathogens found in the child population were Ascaris lumbricoides (56.3\%), Giardia intestinalis (32.5\%) and Hymenolepis nana (15\%). The most common pathogens found in the adult population were Ascaris lumbricoides (67.2\%) and Giardia intestinalis (23.4\%) (Table 1).

Ascaris lumbricoides infection was significantly more common in boys $(p=0.0110)$. As for other infections, no statistically significant differences between genders were observed. In the adult population, infections with Ascaris lumbricoides and Taenia spp. were significantly more prevalent in women than in men ( $p=0.0416$ and $p=0.0277$, respectively) (Table 2 ).

\section{Patients treated in Bagram Korean Hospital \\ $(n=162)$}

It was demonstrated that $30.2 \%$ of the study population, consisting of 162 subjects ( 93 children and 69 adults), were infected with intestinal parasites. Of the 93 children who took part in the study, 45 were girls (48.4\%) and 48 were boys (51.6\%); in total, 31 children were found to be infected (33.3\%). Of the 69 adult patients, 40 were women $(58.0 \%)$ and 29 were men (42.0\%); in total, 18 adults were infected (26.1\%). The mean age of the tested children was 8.2 years (range $1-17$ years). As for the child population, no statistically significant differences in the prevalence of infections between different age groups were observed (the value of the Mann-Whitney $U$ test was $0.65, p=0.5144$ ). The mean age of the adult patients was 29.8 years (range 18-74

Table 1. Number and percentage distribution of intestinal parasites in patients hospitalized in Ghazni Provincial Hospital $(n=386)$ in the period March-April 2013

\begin{tabular}{|c|c|c|c|c|}
\hline \multirow[t]{2}{*}{ Intestinal parasites } & \multicolumn{2}{|l|}{ Children } & \multicolumn{2}{|l|}{ Adults } \\
\hline & $\begin{array}{l}\text { Number and percentage } \\
\text { of infected patients } \\
(n=80)\end{array}$ & $\begin{array}{l}\text { Percentage of tested } \\
\text { patients }(n=179)\end{array}$ & $\begin{array}{l}\text { Number and percentage } \\
\text { of infected patients } \\
(n=64)\end{array}$ & $\begin{array}{l}\text { Percentage of tested } \\
\text { patients }(n=207)\end{array}$ \\
\hline \multicolumn{5}{|l|}{ Nematodes } \\
\hline Ascaris lumbricoides & $45(56.3 \%)$ & $25.1 \%$ & $43(67.2 \%)$ & $20.8 \%$ \\
\hline Enterobius vermicularis & $3(3.8 \%)$ & $1.7 \%$ & $5(7.8 \%)$ & $2.4 \%$ \\
\hline $\begin{array}{l}\text { Ancylostoma duodenale/ } \\
\text { /Necator americanus }\end{array}$ & $1(1.3 \%)$ & $0.6 \%$ & $1(1.6 \%)$ & $0.5 \%$ \\
\hline \multicolumn{5}{|l|}{ Cestodes } \\
\hline Hymenolepis nana & $12(15 \%)$ & $6.7 \%$ & $5(7.8 \%)$ & $2.4 \%$ \\
\hline Hymenolepis diminuta & $6(7.5 \%)$ & $3.4 \%$ & $1(1.6 \%)$ & $0.5 \%$ \\
\hline Taenia spp. & $2(2.5 \%)$ & $1.1 \%$ & $6(9.4 \%)$ & $2.9 \%$ \\
\hline \multicolumn{5}{|l|}{ Trematodes } \\
\hline Dicrocoelium dendriticum & $2(2.6 \%)$ & $1.2 \%$ & $5(7.8 \%)$ & $2.4 \%$ \\
\hline \multicolumn{5}{|l|}{ Protozoa } \\
\hline Giardia intestinalis & $26(32.5 \%)$ & $14.5 \%$ & $15(23.4 \%)$ & $7.2 \%$ \\
\hline $\begin{array}{l}\text { Entamoeba histolytica } \\
\text { sensu lato }\end{array}$ & $1(1.3 \%)$ & $0.6 \%$ & $1(1.6 \%)$ & $0.5 \%$ \\
\hline
\end{tabular}

Table 2. Distribution of the most common infections in patients hospitalized in Ghazni Provincial Hospital $(n=386)$ in the period

\section{March-April 2013, by gender}

\begin{tabular}{|c|c|c|c|c|c|c|}
\hline \multirow[t]{2}{*}{ Intestinal parasites } & \multicolumn{3}{|l|}{ Children } & \multicolumn{3}{|l|}{ Adults } \\
\hline & $\begin{array}{l}\text { Female } \\
(n=85)\end{array}$ & Male $(n=94)$ & $p$-value & $\begin{array}{l}\text { Female } \\
(n=116)\end{array}$ & Male $(n=91)$ & $p$-value \\
\hline Ascaris lumbricoides & $14(16.5 \%)$ & $31(33 \%)$ & 0.0110 & $30(25.9 \%)$ & $13(14.3 \%)$ & 0.0416 \\
\hline Hymenolepis nana & $8(9.4 \%)$ & $4(4.3 \%)$ & 0.1684 & $2(1.7 \%)$ & $3(3.3 \%)$ & 0.4645 \\
\hline Taenia spp. & $1(1.2 \%)$ & $1(1.1 \%)$ & 0.9429 & $6(5.2 \%)$ & $0(0 \%)$ & 0.0277 \\
\hline Giardia intestinalis & $12(14.1 \%)$ & 14 (14.9\%) & 0.8830 & $6(5.2 \%)$ & $9(9.9 \%)$ & 0.1938 \\
\hline
\end{tabular}

Table 3. Number and percentage distribution of intestinal parasites in patients hospitalized in Bagram Korean Hospital $(n=162)$ in the period October-November 2014

\begin{tabular}{|l|l|l|l|l|}
\hline \multirow{2}{*}{ Intestinal parasites } & \multicolumn{2}{|l|}{ Children } & \multicolumn{2}{l|}{ Adults } \\
\cline { 2 - 5 } & $\begin{array}{l}\text { Number and percentage } \\
\text { of infected patients } \\
(n=31)\end{array}$ & $\begin{array}{l}\text { Percentage of tested } \\
\text { patients }(n=93)\end{array}$ & $\begin{array}{l}\text { Number and percentage } \\
\text { of infected patients } \\
(n=18)\end{array}$ & $\begin{array}{l}\text { Percentage of tested } \\
\text { patients }(n=69)\end{array}$ \\
\hline Nematodes & \multicolumn{5}{|l}{} \\
\hline Ascaris lumbricoides & $10(32.3 \%)$ & $10.8 \%$ & $9(50 \%)$ & $13 \%$ \\
\hline Enterobius vermicularis & $2(6.5 \%)$ & $2.2 \%$ & - & - \\
\hline Trichuris trichiura & $1(3.2 \%)$ & $1.1 \%$ & - & - \\
\hline
\end{tabular}




\begin{tabular}{|c|c|c|c|c|}
\hline \multirow{2}{*}{ Intestinal parasites } & \multicolumn{2}{|l|}{ Children } & \multicolumn{2}{|l|}{ Adults } \\
\hline & $\begin{array}{l}\text { Number and percentage } \\
\text { of infected patients } \\
(n=31)\end{array}$ & $\begin{array}{l}\text { Percentage of tested } \\
\text { patients }(n=93)\end{array}$ & $\begin{array}{l}\text { Number and percentage } \\
\text { of infected patients } \\
(n=18)\end{array}$ & $\begin{array}{l}\text { Percentage of tested } \\
\text { patients }(n=69)\end{array}$ \\
\hline \multicolumn{5}{|l|}{ Cestodes } \\
\hline Hymenolepis nana & $5(16.1 \%)$ & $5.4 \%$ & - & - \\
\hline Hymenolepis diminuta & $1(3.2 \%)$ & $1.1 \%$ & - & - \\
\hline Taenia spp. & - & - & $1(5.6 \%)$ & $1.4 \%$ \\
\hline \multicolumn{5}{|l|}{ Protozoa } \\
\hline Giardia intestinalis & $16(51.6 \%)$ & $17.2 \%$ & 7 (38.9\%) & $10.1 \%$ \\
\hline $\begin{array}{l}\text { Entamoeba histolytica } \\
\text { sensu lato }\end{array}$ & 1 (3.2\%) & $1.1 \%$ & $3(16.7 \%)$ & $4.3 \%$ \\
\hline
\end{tabular}

Table 4. Distribution of the most common infections in patients hospitalized in Bagram Korean Hospital $(n=162)$ in the period October-November 2014, by gender

\begin{tabular}{|l|l|l|l|l|l|l|}
\hline \multirow{2}{*}{ Intestinal parasites } & \multicolumn{4}{l|}{ Children } & \multicolumn{2}{l|}{ Adults } \\
\cline { 2 - 8 } & Female $(n=45)$ & Male $(n=48)$ & $p$-value & Female $(n=40)$ & Male $(n=29)$ & $p$-value \\
\hline Ascaris lumbricoides & $7(15.6 \%)$ & $3(6.3 \%)$ & 0.1477 & $5(12.5 \%)$ & $4(13.8 \%)$ & 0.8749 \\
\hline Hymenolepis nana & $4(8.9 \%)$ & $1(2.1 \%)$ & 0.1459 & - & - & - \\
\hline Giardia intestinalis & $6(13.3 \%)$ & $10(20.8 \%)$ & 0.3382 & $5(12.5 \%)$ & $2(6.9 \%)$ & 0.4467 \\
\hline
\end{tabular}

years). The infected patients were significantly older (the value of the Mann-Whitney $U$ test was $-2.56, p=0.0104$ ). The most common pathogens found in the child population were Giardia intestinalis (51.6\%), Ascaris lumbricoides (32.3\%) and Hymenolepis nana (16.1\%). The most common pathogens found in the adult population were Ascaris lumbricoides (50\%) and Giardia intestinalis (38.9\%) (Table 3).

We have not observed any statistically significant differences in the prevalence of infections between genders, both in adults and in children (Table 4).

\section{Discussion}

The overall prevalence of intestinal parasitic infections in this study (total $35.2 \%$; $40.8 \%$ in children and $29.7 \%$ in adults) was comparable to the infection rates reported by the countries bordering Afghanistan. The overall prevalence of infections with helminths and protozoa among 602 children attending primary schools in Tajikistan was $32 \%$ and $47.1 \%$, respectively, with the most commonly detected being Giardia intestinalis (26.6\%), Entamoeba histolytica sensu lato (25.9\%) and Hymenolepis nana (25.8\%) [17]. Parasitological examination of stool samples collected from 269 children hospitalized in Karachi (Pakistan) demonstrated the presence of parasitic infections in $68.8 \%$ of individuals, with the most commonly detected being Giardia intestinalis (25.3\%), Entamoeba histolytica (19.3\%) and Ascaris lumbricoides (12.3\%) [18]. Another study of 150 children hospitalized in Bannu (Pakistan) revealed the presence of parasitic infections in $65.3 \%$ of patients, the most common pathogens being Ascaris lumbricoides (18\%) and Hymenolepis nana (15\%) [19]. In contrast, the prevalence rates of parasitic infections observed in Iran are significantly lower. The studies of 1,000 patients aged 1-80 hospitalized in Tehran revealed infections with pathogenic parasites only in $3 \%$ of patients, the most commonly detected pathogen being Giardia intestinalis (2.5\%) [20]. Parasitological examination of stool samples taken from 13,915 children and adults in Karaj City, Tehran province, demonstrated the presence of intestinal parasites in $4.0 \%$ patients, with the most common being Giardia intestinalis (3.8\%) [21]. In Afghanistan, Tajikistan and Pakistan, the prevalence rates of parasitoses as well as the types of most common intestinal parasites are roughly the same. In contrast, the prevalence of intestinal parasitic infections in Iran is lower than in any of the three countries, with only a small proportion of helminthic infections.

Our study demonstrated significant divergency in terms of the correlation between gender and the presence of parasites. In the Ghazni Provincial Hospital in Afghanistan, infections with Ascaris lumbricoides were more common among infected boys; as for the adult population, Ascaris lumbricoides and Taenia spp. infections were more prevalent in women. As a comparison, the tests for Giardia intestinalis and Hymenolepis nana conducted among 687 Afghan migrants to Pakistan showed a higher prevalence of both parasites in children (1-15 years) and in women as compared to men [8]. On the other hand, of the 1,520 patients who had been referred to clinical laboratories in a few cities of Iran, the most common detected pathogen, Giardia intestinalis $(2.3 \%$ infected), was more prevalent in men than in women (62.9\% vs. $37.1 \%)$, as well as in the group of children [22].

It is estimated that intestinal polyparasitism is widespread in the MENA region (Middle East and North Africa, including Afghanistan) [23]. In Pakistan, $13.9 \%$ of patients were co-infected with ascariasis and giardiasis [24]. In Iran, polyparasitism was detected in $2 \%$ of school children in Tehran, $8.2 \%$ of food sellers in Kashan, $5.8 \%$ of students from Hormozgan and $0.8 \%$ of children attending day-care centers in Tehran [25]. In our study, parasitic co-infections were observed both in hospitalized adults and in children. In the Ghazni province, polyparasitism was reported in $7.3 \%$ of treated patients ( $13.3 \%$ adults and $3.9 \%$ children), in the Parwan province - in $4.3 \%$ patients $(7.2 \%$ adults and $2.1 \%$ children). Co-infections of Ascaris lumbricoides + Giardia intestinalis, Ascaris lumbricoides + Hymenolepis nana and Giardia intestinalis + Hymenolepis nana were the most common.

Parasitological examination of stool samples from Afghan inhabitants allowed us to identify the species of the most prevalent intestinal parasites and to estimate current infection rates in eastern Afghanistan. Our study demonstrates that general screening should become routine if parasitic pathogens are to be eliminated from the local population. The parasitological tests performed for the purposes of our study were carried out by the medical personnel from the Polish Military Contingent serving in Afghanistan and were part of the project funded by the Polish Ministry of National Defense Capacity building of the 
health care system in the Ghazni province. One of the primary objectives of this project was to purchase thousands of doses of antiparasitic drugs in order to treat infected patients hospitalized in Ghazni Provincial Hospital, as well as the children frequenting local schools in the Ghazni province [26]. However, owing to the high prevalence of parasitic infections and the great variety of pathogenic parasites found in Afghans, a deworming campaign with single-dose therapy (albendazole or mebendazole) may turn out to be ineffective. Therefore, the decision to conduct parasitological screening tests which will allow healthcare workers to use targeted antiparasitic chemotherapy seems fully justified. Apart from conducting parasitological screening, it is also important that deworming campaigns are conducted regularly and on a massive scale. In the Republic of Korea, for example, a drastic decrease in the prevalence of parasitic infections was possible due to the introduction of large-scale deworming programs delivered on a regular basis. National surveys on the prevalence of intestinal parasitic infections in the Korean community have been carried out every 5-7 years since 1971. The first survey conducted in 1971 presented an overall helminth egg positive rate of $84.3 \%$ among Koreans. Over the next several years, the Republic of Korea, apart from impressive economic growth, improvement of citizens' personal hygiene practices and raising their awareness of disease prevention, showed a dramatic decrease in the overall helminth egg positive rate, down to $2.4 \%$ in 1997 (e.g. the prevalence rate of Ascaris lumbricoides in Koreans went down from 54.9\% in 1971 to $0.06 \%$ in 1997) [27]. Similarly, the only way to improve the health status of Afghan citizens, as well as to eliminate foodand water-borne diseases from the country, is to introduce comprehensive health protection programs, both at the central and the local level, which will target all parts of the country. Otherwise, all the activities undertaken by international NGOs will only have short-term effects and will not produce spectacular results.

\section{Conclusions}

The rates of intestinal parasitic infections among Afghans are high. The wide range of the detected parasites (protozoa, nematodes, cestodes) should result in the introduction of general screening to be conducted regularly among inhabitants of Afghanistan and the application of targeted antiparasitic chemotherapy aiming to eliminate intestinal helminths and protozoa from the local community. Taking into consideration the fact that thousands of Asian immigrants, including Afghans, have recently flooded into Europe, it has become necessary to investigate and to eliminate the intestinal parasitic infections among foreigners coming from developing countries and have them register in primary care medical centers.

Acknowledgements. The authors are grateful to Dr. Baz Mohammad Hemmat (Head of Ghazni Provincial Hospital) and Dr. Zia Ghul (Head of the Department of Health Service in the Ghazni Province) for their excellent technical assistance and supervision in patient recruitment and collection of biological samples.

Source of funding: This work was funded by the authors' resources. Conflict of interest: The authors declare no conflict of interests.

\section{References}

1. Elyan DS, Monestersky JH, Wasfy MO, et al. Capacity building of public health laboratories in Afghanistan: challenges and successes (2017-2011). EMHJ 2014; 20(2): 112-119.

2. Wallace M, Halle BR, Utz GC, et al. Endemic infectious diseases of Afghanistan. Clin Infect Dis 2002; 34(Suppl. 5): S171-S207.

3. Central Intelligence Agency. The World Factbook - Afghanistan [cited: 30.12.15]. Available at URL: https://www.cia.gov/library/publications/the-world-factbook/geos/af.html.

4. World Health Organization. Countries - Afghanistan [cited: 5.01.16]. Available at URL: http://www.who.int/ countries/afg/en/.

5. Hotez PJ. The neglected tropical diseases and their devastating health and economic impact on the member nations of the Organisation of the Islamic Conference. PLoS Negl Trop Dis 2009; 3(10): e539, doi: 10.1371/journal.pntd.0000539.

6. McCaw BR, DeLay P. Demographics and disease prevalence of two new refugee groups in San Francisco. The Ethiopian and Afghan Refugees. West J Med 1985; 143(2): 271-275.

7. Ekdahl K, Andersson Y. Imported giardiasis: impact of international travel, immigration, and adoption. Am J Trop Med Hyg 2005; $72(6)$ : 825-830.

8. UI Haq KA, Gul NA, Hammad HM, et al. Prevalence of Giardia intestinalis and Hymenolepis nana in Afghan Refugee population of Mianwali district, Pakistan. Afr Health Sci 2015; 15(2): 394-400.

9. Gabrielli AF, Ramsan M, Naumann C, at al. Soil-transmitted helminths and haemoglobin status among Afghan children in World Food Programme assisted schools. J Helminthol 2005; 79(4): 381-384

10. Sharpe W. Largest de-worming campaign in history happens in Afghanistan. Lancet Infect Dis 2004; 4(10): 601.

11. Montresor A. Helminth control in school-aged children: a guide for managers of control programmes. $2^{\text {nd }}$ ed. Geneva: World Health Organization; 2011: 76.

12. World Health Organization. Soil-transmitted helminthiases: number of children treated in 2011. Wekly Epidemiol Rec 2013; 88(14): 145-152.

13. Ik KJ. Bagram Korean Hospital January-December 2013 - medical statistics [cited 02.10.2014]. Unpublished data.

14. World Health Organization. Basic laboratory methods in medical parasitology. Geneva: World Health Organization; 1991.

15. Procedures for the recovery and identification of parasites from the intestinal tract: approved guideline, M28-2A. Wayne, PA: Clinical and Laboratory Standards Institute; 2005

16. Garcia LS, Smith JW, Fritsche TR. Selection and use of laboratory procedures for diagnosis of parasitic infections of the gastrointestinal tract. Washington D.C.: ASM Press; 2003.

17. Matthys B, Bobieva M, Karimova G, et al. Prevalence and risk factors of helminths and intestinal protozoa infections among children from primary schools in Western Tajikistan. Parasit Vectors 2011; 4: 195.

18. Mumtaz S, Siddiqui $\mathrm{H}$, Ashfaq T. Frequency and risk factors for intestinal parasitic infection in children under five years age at a tertiary care hospital in Karachi. J Pak Med Assoc 2009; 59(4): 216-219.

19. Ahmed W, Ahmad M, Rafatullah, et al. Pervasiveness of intestinal protozoan and worm incursion in IDP's (North Waziristan agency, KPK-Pakistan) children of 6-16 years. J Pak Med Assoc 2015; 65(9): 943-945.

20. Akhlaghi L, Shamseddin J, Meamar AR, et al. Frequency of intestinal parasites in Tehran. Iranian J Parasitol 2009; 4(2): 44-47.

21. Nasiri V, Esmailnia K, Karimi G, et al. Intestinal parasitic infections among inhanitants of Karaj City, Tehran Province, Iran in 2006-2008. Korean J Parasitol 2009; 47(3): 265-268. 
22. Zebadast N, Gharavi MJ, Abadi A, et al. Frequency of intestinal parasites in patients with gastrointestinal disorders, in different parts of Iran During 2012-2013. Int J Enteric Pathog 2015; 3(1): e22682.

23. Rokni MB, Lotfy WM, Hotez PJ, et al. Soil-Transmitted Helminth (STH) Infections in the MENA Region. In: McDowell MA, Rafati S, eds. Neglected tropical diseases - Middle East and North Africa. Wien: Springer-Verlag; 2014: 1-22.

24. Mehraj V, Hatcher J, Akhtar S, et al. Prevalence and factors associated with intestinal parasitic infection among children in an Urban Slum of Karachi. PLoS One 2008; 3(11): e3680.

25. Rokni M. The present status of human helminthic diseases in Iran. Ann Trop Med Parasitol 2012; 102(4): 283-295.

26. Korzeniewski K, Augustynowicz A, Smoleń A, et al. Epidemiology of intestinal parasitic infections in school children in Ghazni Province, eastern Afghanistan. Pak J Med Sci 2015; 31(6): 1421-1426.

27. Kim TS, Cho SH, Huh S, et al. Working Groups in National Institute of Health; Korea Association of Health Promotion. A nationwide survey on the prevalence of intestinal parasitic infections in the Republic of Korea, 2004. Korean J Parasitol 2009; 47(1): 37-47.

Tables: 4

Figures: 0

References: 27

Received: 12.12.2016

Revised: 03.01.2017

Accepted: 03.01.2017

Address for correspondence:

Col. Krzysztof Korzeniewski, MD, PhD, Assoc. Prof.

Zakład Epidemiologii i Medycyny Tropikalnej WIM

ul. Grudzińskiego 4

81-103 Gdynia

Polska

Tel.: +48 261 266-523

E-mail: kktropmed@wp.pl 